\title{
Incidence of Helicobacter pylori strains activating neutrophils in patients with peptic ulcer disease
}

\author{
H Rautelin, B Blomberg, H Fredlund, G Järnerot, D Danielsson
}

\begin{abstract}
A total of 61 human gastric isolates of Helicobacter pylori were studied for their ability to induce an oxidative burst in human neutrophils measured by luminol enhanced chemiluminescence. About one third of the strains induced strong and rapid chemiluminescence in neutrophils even without serum opsonins and agglutinated these cells on glass slides within two minutes. For other strains complement was required, although even then the reactions remained at a lower level. The activating and agglutinating property was bound to the cells, heat labile, and sensitive to several enzymes but resistant to acid. Strains possessing such activity were more common in patients with peptic ulcer disease than in patients with active chronic gastritis only $(p=0.0261$, Fisher's exact test, two tailed). The activity shown might be a new indicator for ulcerogenic strains and could also partly explain the accumulation of neutrophils in the gastric mucosa during $\boldsymbol{H}$ pylori infection.

(Gut 1993; 34: 599-603)
\end{abstract}

The association of Helicobacter pylori ( $H$ pylori) with gastroduodenal disease was first shown by Warren and Marshall. ${ }^{1}$ Although the causal pathogenic relation between $H$ pylori and active chronic gastritis is accepted, ${ }^{23}$ the exact pathogenetic mechanisms are not known. A heavy gastric infiltrate of polymorphonuclear leucocytes (PMNLs) and lymphocytes, ${ }^{\prime}$ and both local and circulating antibodies indicate a profound immune reaction. ${ }^{4}$ Despite this, a chronic $H$ pylori infection may persist for years. ${ }^{5}$ Many patients, however, remain symptom free and few develop peptic ulcer disease. This might indicate that some $H$ pylori strains are more virulent than others. Such a hypothesis is supported by the findings in our study where $H$ pylori strains, capable of activating and agglutinating neutrophils, were found significantly more often in patients with peptic ulcer disease than in those with active chronic gastritis only.

\section{Patients and methods}

HELICOBACTER PYLORI STRAINS AND PATIENTS

A total of 61 isolates of $H$ pylori from human gastric biopsies were included in the study. All the strains were oxidase, catalase, and urease positive, and showed typical morphology with Gram stain. The individual strains were stored at $-70^{\circ} \mathrm{C}$ before use. For the in vitro experiments the strains were grown for 48-72 hours on GC agar plates (GC II agar base, BBL, Cockeysville, $M D$, USA, supplemented with $1 \%$ bovine haemoglobin (BBL), 10\% horse serum, and 1\% IsoVitaleX) without antibiotics. All the strains were tested for the induction of chemiluminescence in neutrophils and for agglutination of these cells. Six strains were selected and used in extended experiments and will be referred to as reference strains; one strain designated NCTC 11637 from the National Collection of Type Cultures, one Canadian strain designated C 7050, two Finnish strains, F 6 and F 88, and two Swedish strains, S206 and S 210. The rationale for selecting these six strains was threefold; in preliminary experiments they behaved differently in the chemiluminescence, they originated from patients in four different countries, and were shown in a previous study to express different serological patterns with homologous and heterologous hyperimmune rabbit $H$ pylori antisera. ${ }^{6}$ The remaining 55 strains were isolated from gastric biopsies from an unselected group of 210 consecutive patients referred for upper gastrointestinal endoscopy. The endoscopic findings and the presence or absence of peptic ulcer disease were recorded. The gastric biopsies were evaluated histologically for the type of gastritis as described. ${ }^{7}$ The medical records of Helicobacter pylori positive patients in whom the endoscopy did not show peptic ulcer were examined to find those in whom peptic ulcer disease had been diagnosed earlier.

The six $H$ pylori reference strains had undergone multiple subcultures whereas the 55 recent isolates were subcultured four or five times before being studied. The reference strains were tested for hydrophobicity with the salt aggregation test, and for mannose resistant and mannose sensitive haemagglutination of erythrocytes from humans, sheep, and rabbits as described elsewhere. ${ }^{8}$ Organisms of these strains were subjected to heat treatment at temperatures of $45^{\circ} \mathrm{C}$ to $90^{\circ} \mathrm{C}$ or boiling for 30 minutes or to different treatments for 30 minutes at $37^{\circ} \mathrm{C}$ namely, in $\mathrm{NaN}_{3}(0.5 \%$ w/v in $0.03 \mathrm{M}$ Tris, $\mathrm{pH}$ $7 \cdot 0$ ), trypsin (Sigma, St Louis, MO, USA, 0.5\%

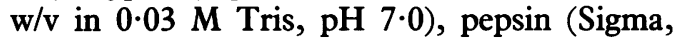
$0.5 \% \mathrm{w} / \mathrm{v}$ in $0.03 \mathrm{M}$ Tris, $\mathrm{pH} 2.3$ ), glycine hydrochloride $(0 \cdot 2 \mathrm{M}, \mathrm{pH} 2 \cdot 2)$, or formalin (3\% in phosphate buffered saline (PBS)). After treatment the organisms were washed and suspended in PBS and then used in tests to induce chemiluminescence in neutrophils and to agglutinate these cells in parallel with live organisms of the same strains. Also, organisms of the six reference strains were disrupted by ultrasonic treatment with an MSE $20 \mathrm{Kc}$ ultrasonic oscillator operated at maximum efficiency. Outer membrane preparations were made from three of the six reference strains, NCTC 11637, C 7050, and F 88 according to the method of Tam et al. ${ }^{9}$ The 
suspensions of disrupted cells, the supernatants and the sediments obtained after centrifugation at $10000 \mathrm{~g}$ for 30 minutes as well as the outer membrane preparations adjusted to correspond to an original concentration of $10^{9}$ organisms $/ \mathrm{ml}$ were used in parallel with live organisms of the same strains to induce chemiluminescence in neutrophils and to agglutinate these cells.

\section{HELICOBACTER PYLORI SERUM ANTIBODIES}

Serum was taken from six patients with known $H$ pylori state, from two children, and from six members of our laboratory staff who were also used as donors of PMNLs. The serum samples were divided into small portions and kept frozen at $-70^{\circ} \mathrm{C}$ before use. All serum samples showed normal complement mediated haemolytic activity. The concentrations of IgG, IgA, IgM, and subclasses of IgG were within normal limits.

Helicobacter pylori serum antibodies of IgG, $\operatorname{IgM}$, and IgA classes were measured with an enzyme immunoassay (EIA) with the use of an acid glycine extract from $H$ pylori strain NCTC 11637 as the antigen. ${ }^{10}$ For the absorption of $H$ pylori antibodies $0.5 \mathrm{ml}$ of a serum sample was mixed with an equal volume of packed bacteria (obtained by centrifugation of strains NCTC 11637 or $\mathrm{C} 7050$ for 20 minutes at $2000 \mathrm{~g}$ ), incubated at $0^{\circ} \mathrm{C}$ for 30 minutes, and centrifuged twice to remove bacteria. No specific antibodies were found after the absorption whereas the complement mediated haemolytic activity of the serum was retained.

\section{SERUM BACTERICIDAL TESTS}

For serum bactericidal tests $0.2 \mathrm{ml}$ of serum diluted 1:10 (untreated or heated at $56^{\circ} \mathrm{C}$ for 30 minutes, or absorbed with $H$ pylori) was mixed with $0.2 \mathrm{ml}$ of freshly prepared $H$ pylori organisms $\left(10^{7} / \mathrm{ml}\right.$, in a total volume of $0.8 \mathrm{ml}$ of the buffer used (Hank's balanced salt solution with $0 \cdot 1 \%$ gelatin, HBSS-gel)). The mixtures were incubated at $37^{\circ} \mathrm{C}$ and viable colony forming units (CFU) were counted at time 0 , and after 15 , 30 , and 90 minutes by serial dilution in sterile PBS and plating on GC agar plates. Controls consisted of serum replaced by the buffer used. The time 0 value was used to calculate the $\log _{10}$ values of the decreases or increases of $\mathrm{CFU} / \mathrm{ml}$.

\section{PREPARATION OF POLYMORPHONUCLEAR LEUCOCYTES}

Heparinised blood was taken from $H$ pylori antibody negative or antibody positive members of our staff. For each series of experiments on a particular day, blood from a single donor was used. To obtain PMNLs the method of Böyum was used with minor modifications. ${ }^{112}$ The purity and viability of the PMNL suspensions was more than $95 \%$.

\section{PHAGOCYTOSIS ASSAYS}

The phagocytosis and killing of $H$ pylori by PMNLs were studied by mixing $0.2 \mathrm{ml}$ of bacteria $\left(10^{7} / \mathrm{ml}\right)$ with $0.2 \mathrm{ml}$ of PMNL $\left(10^{7} / \mathrm{ml}\right)$ and $0.2 \mathrm{ml}$ of serum (diluted $1: 10$ ), untreated or heated at $56^{\circ} \mathrm{C}$, in a final volume of $0.8 \mathrm{ml}$ of HBSS-gel. Controls consisted of serum or PMNL or both replaced by HBSS-gel. The mixtures were slowly tumbled at $37^{\circ} \mathrm{C}$ and aliquots were removed at $0,15,30$, and 90 minutes to measure the $\mathrm{CFU} / \mathrm{ml}$. The time 0 value of the control mixture with bacteria alone in HBSS-gel was used to calculate the $\log _{10}$ values of the decreases or increases of $\mathrm{CFU} / \mathrm{ml}$.

The uptake of bacteria by PMNLs in the presence or absence of $H$ pylori positive or negative serum was also examined by microscopy. In these experiments one volume of $2-5 \times 10^{8}$ bacteria $/ \mathrm{ml}$ was mixed and incubated with one volume of $10^{7} \mathrm{PMNLs} / \mathrm{ml}$ and serum. Slides were prepared at times $0,5,10,15,30$, and 60 minutes by placing $0.05 \mathrm{ml}$ of the mixture on a glass slide treated with egg white and glycerin. The slides were dried in air, gently fixed by heat, and then stained with acridine orange. ${ }^{13}$ The slides were examined with a fluorescence microscope with oil immersion objectives (Zeiss epiplan, $50 \mathrm{w}$ halogen lamp).

\section{CHEMILUMINESCENCE}

The induction of chemiluminescence in PMNLs by $H$ pylori in the presence or absence of serum was studied by luminol enhanced chemiluminescence. For each experiment $200 \mu \mathrm{l}$ of PBS, $100 \mu \mathrm{l}$ of serum, $100 \mu \mathrm{l}$ of the PMNL suspension $\left(10^{7} / \mathrm{ml}\right), 50 \mu$ l of $10^{-5} \mathrm{M}$ luminol (Sigma), and $50 \mu \mathrm{l}$ of the bacterial suspension $\left(10^{9} / \mathrm{ml}\right)$ were added to each test tube (LKB, Bromma, Sweden). The measurements with a luminometer (LKB Wallac 1251, Turku, Finland) were always started within one minute after the bacterial suspension had been added, and all tests were run within three hours of collection of the blood samples for the preparation of PMNLs. The assays were performed at $37^{\circ} \mathrm{C}$ with continuous mixing in the measurement chamber. Chemiluminescence from each sample was measured at 70-90 second intervals for at least 30 minutes. A Staphylococcus epidermidis strain (strain L-9 of our strain collection), inducing stable and reproducible chemiluminescence responses of PMNLs, was run in each test as a control. ${ }^{12}$

\section{SLIDE AGGLUTINATION TEST OF PMNLS AND HELICOBACTER PYLORI}

One drop of a suspension of PMNLs $\left(10^{7} / \mathrm{ml}\right)$ was mixed on a glass slide with one drop of a bacterial suspension $(10 \% / \mathrm{ml})$. The slide was then tilted about once a second for two minutes, after which the reactions were recorded as positive or negative.

\section{Results}

TWO PATTERNS OF INTERACTION WITH NEUTROPHILS

After opsonisation with anti $H$ pylori positive or negative serum the six $H$ pylori reference strains regularly induced chemiluminescence responses in PMNLs (Fig 1). Under corresponding conditions they were phagocytosed (judged by micro- 


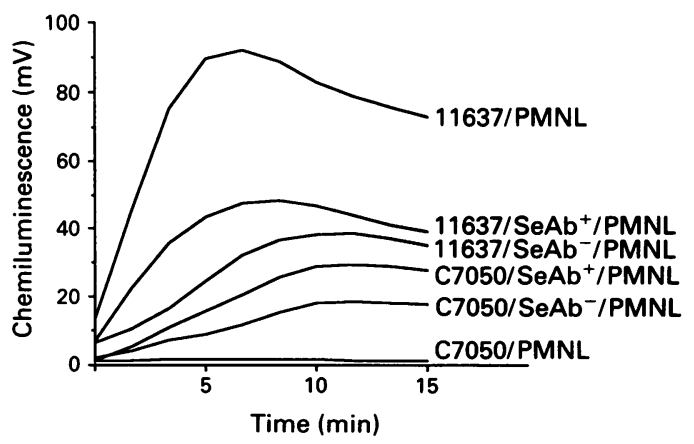

Figure 1: Chemiluminescence induced in polymorphonuclear leucocytes (PMNLs), by Helicobacter pylori strains NCTC 11637 and $C 7050$, either without opsonising serum, or in the presence of serum with $\left(\mathrm{SeA} b^{+}\right)$or without $\left(\mathrm{S} e A b^{-}\right)$specific antibodies. Results shown from a representative test run.

scopy) and killed in the phagocytic killing experiments (Fig 2). Serum bactericidal tests showed that the strains were sensitive both to anti $H$ pylori positive and negative serum (Fig 2), even after serum was absorbed for specific antibodies. This serum sensitivity remained after Clq was removed by treatment with $10 \mathrm{mM}$ ethylene glycol tetra-acetate (EGTA) ${ }^{14}$ but was abolished after the serum was heated at $56^{\circ} \mathrm{C}$ for 30 minutes, which also resulted in no phagocytic killing. Organisms opsonised with EGTA treated serum gave comparable chemiluminescence results with untreated serum whereas heat treated serum was a poor opsonin.

Organisms of the strains NCTC 11637, F 6, and S 206 but not those of C 7050, F 88, and $S 210$ induced even stronger chemiluminescence responses unopsonised (Fig 1), whether the neutrophils were from donors with or without $H$ pylori antibodies. Although there were some day to day variations in the peaks of chemiluminescence responses with PMNLs from different neutrophil donors and also within the same donor, the patterns were consistent. The strains NCTC 11637, F 6, and S 206 thus induced strong and rapid chemiluminescence responses with peaks, measured in $\mathrm{mV}$, within five to 15 minutes. The strains C 7050, F 88, and

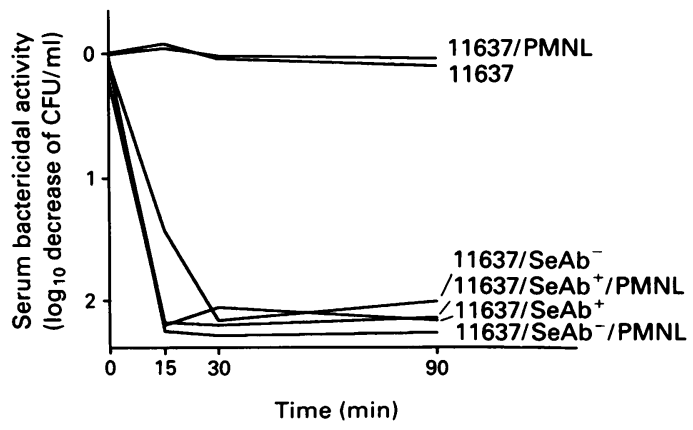

Figure 2: Serum bactericidal activity against Helicobacter pylori and phagocytic killing. For bactericidal tests $\mathbf{H}$ pylori NCTC 11637 organisms were added to serum with $\left(S e A b^{+}\right)$or without $\left(\mathrm{SeAb} \mathrm{b}^{-}\right) \mathrm{H}$ pylori specific antibodies. For phagocytic without $\left(S e A b^{-}\right) \mathrm{H}$ pylori specific antibodies. For phagocytic
killing polymorphonuclear leucocytes (PMNLs) were added to mixtures of bacteria and serum with or without $\mathbf{H}$ pylori antibodies. Control mixtures included bacteria alone in buffer, or bacteria with PMNLs. Aliquots were removed from each mixture after $0,15,30$, and 90 minutes of incubation, serially diluted, and plated to determine the decrease of colony forming units $(C F U) / m l$ at each time point. Results are shown from $a$ representative experiment.
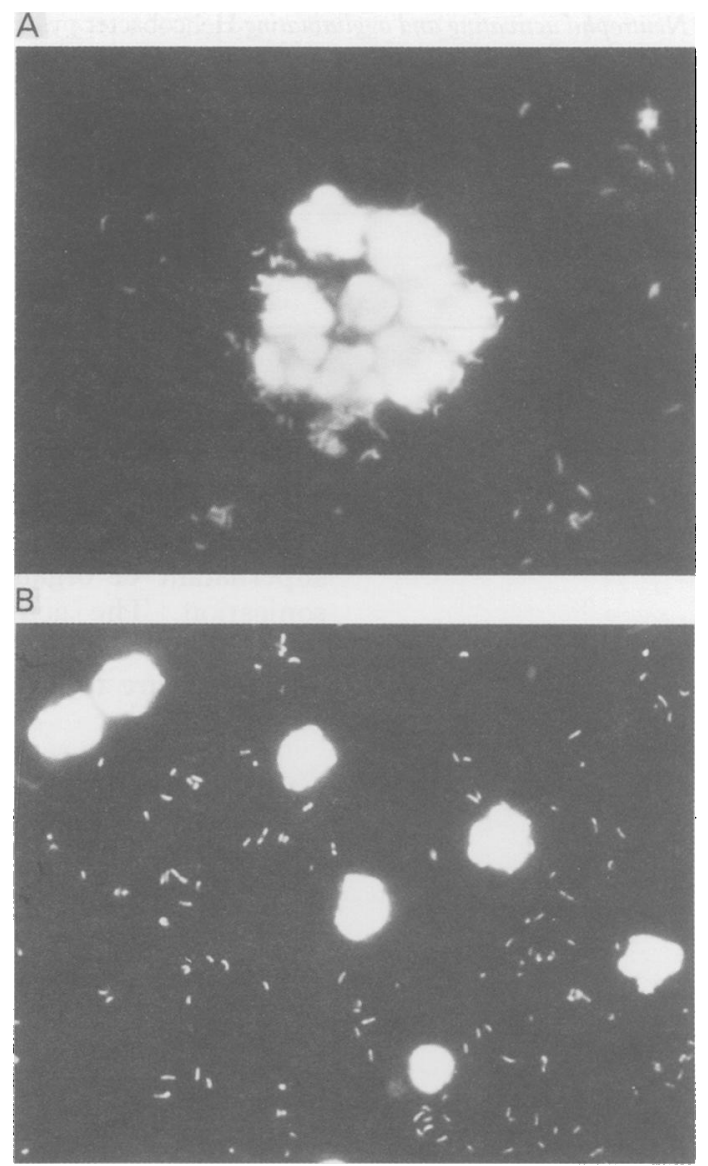

Figure 3: Interaction of Helicobacter pylori NCTC 11637 and $C 7050$ with neutrophils stained with acridine orange after incubation for 15 minutes. Unopsonised organisms of NCTC 11637 have agglutinated neutrophils that also show phagocytosed bacteria (A). Neutrophils and unopsonised organisms of $C 7050$ are randomly distributed, with neither agglutination nor phagocytosis $(B)$.

S 206 induced weak ( $<30 \%$ of mean $\mathrm{mVs}$ of strains NCTC 11637, F 6, and S 206) and slow responses with peaks (mV) after 15 minutes. These two patterns were also found in the unselected clinical isolates.

Studies by microscopy showed that unopsonised $H$ pylori organisms of the strains NCTC $11637, F 6$, and S 206 attached rapidly to the neutrophils, and were phagocytosed (Fig 3). These findings were confirmed by electron microscopy (data not shown). No phagocytic killing was noted, however, unless complement was added (Fig 2). Agglutination of neutrophils could also be seen on a glass slide within two minutes of mixing and tilting one drop each of bacteria and neutrophils. No such agglutinations were found with neutrophils and $H$ pylori of C 7050, F 88, and S 210 strains. Slide agglutination and chemiluminescence tests of the 55 unselected $H$ pylor i isolates also agreed.

EFFECTS OF PHYSICAL AND CHEMICAL TREATMENT; LACK OF CORRELATION WITH

HAEMAGGLUTINATION AND SURFACE

HYDROPHOBICITY

The $H$ pylori organisms of the reference strains NCTC 11637, F 6, and S 206 lost their ability to agglutinate neutrophils and induce chemiluminescence responses after treatment with 
Neutrophil activating and agglutinating Helicobacter pylori strains isolated from patients with peptic ulcer disease and from those with chronic gastritis only.

\begin{tabular}{llll}
\hline & \multicolumn{2}{l}{ H pylori positive patients } & \\
\cline { 2 - 4 } $\begin{array}{l}\text { Neutrophil activating and agglutinating } \\
\text { property of isolates of H pylori }\end{array}$ & $\begin{array}{l}\text { Nowith peptic ulcer } \\
\text { disease }\end{array}$ & $\begin{array}{l}\text { Nowith chronic } \\
\text { gastritis only }\end{array}$ & Total \\
\hline Present & 14 & 6 & 20 \\
Absent & 13 & 22 & 35 \\
Total & 27 & 28 & 55 \\
\hline
\end{tabular}

trypsin (pH 7.0), pepsin (pH 2.3), formalin, or heat $\geqslant 50^{\circ} \mathrm{C}$. Outer membrane preparations of $H$ pylori cells could not activate or agglutinate PMNLs, nor could the sediment or the supernatant of organisms disrupted by ultrasonication. The activation and agglutination properties of $H$ pylori were, however, preserved after exposure to glycine hydrochloride and to $\mathrm{NaN}_{3}$.

The PMNL agglutination showed no correlation with haemagglutination patterns of the six $H$ pylori reference strains, five of which showed mannose resistant haemagglutination of human, rabbit, and sheep erythrocytes, and one (S 210) which did not agglutinate sheep red cells but showed weak mannose resistant agglutination of human and rabbit red cells. All strains showed low relative hydrophobicity (salt aggregation test $\geqslant 5 \cdot 12$ ) regardless of the chemiluminescence patterns.

\section{NEUTROPHIL ACTIVATING AND AGGLUTINATING PATTERNS OF H PYLORI STRAINS AND}

CORRELATION WITH GASTRODUODENAL DISEASE At endoscopy active peptic ulcer disease was found in 12 patients (three with duodenal, four with gastric, one with both, and four with prepyloric ulcers). Fifteen patients without an overt ulcer at endoscopy had earlier verified ulcer disease. Twenty eight patients had active chronic gastritis without known peptic ulcer disease. The $55 H$ pylori strains isolated from these patients were tested for their ability to induce chemiluminescence responses and to agglutinate neutrophils (Table). Fourteen out of $20 \mathrm{H}$ pylori strains with neutrophil activating and agglutinating properties were found in patients with peptic ulcer disease. The difference in comparison with patients with active chronic gastritis without verified peptic ulcer disease was significant $(p=0.0261$, Fisher's exact test, two tailed). The difference was also significant when calculated as the odds ratio (OR) $(1 \cdot 198<$ OR $<13 \cdot 39$, 95\% confidence interval with mid $p$ adjustment). ${ }^{15}$ No difference was found between patients with different locations of the ulcer (gastric, prepyloric, or duodenal).

\section{Discussion}

Our study showed that $H$ pylori strains could be divided into two main groups on the basis of their interaction with PMNLs. In the absence of opsonins about one third of the $H$ pylori strains isolated from gastric biopsies of an unselected and consecutive group of patients with gastroduodenal disease induced a rapid and strong oxidative burst in the neutrophils, which were also rapidly agglutinated by the organisms of these particular strains. The unopsonised bacteria were obviously phagocytosed, as confirmed by electron microscopy, but no phagocytic killing occurred. The oxidative burst in phagocytosis might, however, liberate free radicals and so cause cell damage. ${ }^{16}$ It is therefore of particular clinical interest that 14 out of the 20 (70\%) strains that activated and agglutinated neutrophils, occurred in patients with peptic ulcer disease. This finding may indicate that some $H$ pylori strains are more ulcerogenic than others. The factors responsible for the described activity were found to be bound to the cells, as well as sensitive to heat $\left(\geqslant 50^{\circ} \mathrm{C}\right)$ and several peptic enzymes. These properties indicate that they might be proteins or peptides. Formalin treatment also abolished the activity that was preserved after treatment of the organisms with acid glycine.

Other research groups have also studied chemiluminescence induced in PMNLs by $H$ pylori organisms and found results corresponding to ours with opsonised organisms. ${ }^{17-19}$ They reported only low responses, however, with unopsonised organisms. The small number of isolates tested by Das et al might have belonged to the group of $H$ pylori strains that does not have the properties described in the present study..$^{17}$ Other researchers used heat killed organisms. ${ }^{1819}$ This might explain why they did not detect this heat labile activity in their isolates.

Both types of $H$ pylori strains were phagocytosed and the number of organisms significantly reduced $(\geqslant 99.9 \%)$ in phagocytic killing tests in the presence of serum with or without $H$ pylori antibodies. These findings are in agreement with those described by others. ${ }^{17} \mathrm{We}$ also found that the killing was mainly due to the sensitivity of $H$ pylori organisms to normal serum and that this sensitivity was in fact dependent on the alternative complement pathway as reported by Das et al. ${ }^{17}$ These observations do not, however, preclude the fact that specific $H$ pylori antibodies enhance the complement dependent killing of $H$ pylori organisms. ${ }^{19} 20$

Although $H$ pylori infection is strongly associated with active chronic gastritis and peptic ulcer disease, the mechanisms of pathogenesis are far from understood. The sensitivity of $H$ pylori to normal serum might explain why these organisms do not cause septicaemia and remain localised. $H$ pylori has been shown to produce chemotactic factors that might account to some extent for the accumulation of neutrophils in the gastric mucosa. These factors have been shown to be soluble ${ }^{21}$ or present in sonicates ${ }^{22}$ whereas the activity described in our study was found to be bound to the cells and not present after sonication. It is tempting to speculate that the neutrophil activating and agglutinating properties in one third of our strains might be a relevant virulence factor in the ability of such strains to challenge neutrophils both in the absence and in the presence of serum with or without specific antibodies.

Leunk et al described an extracellular cytotoxin produced by some $H$ pylori strains ${ }^{23}$ that was shown to be associated with duodenal ulcer 
disease. ${ }^{24}$ This cytotoxin causes vacuolisation of cultured cells and can be found in broth culture filtrates of $H$ pylori organisms. It differs from the cell bound factor described in this paper as we have found that broth culture filtrates do not induce chemiluminescence of neutrophils or agglutination of these cells. Our preliminary studies show, however, that most of our cytotoxin producing strains activate and agglutinate PMNLs. Such strains might act on various levels in the pathogenesis of gastritis and peptic ulcer diseases.

Most $H$ pylori infected patients have minor clinical symptoms, if any, and only a few of them will ever develop a peptic ulcer, a disease certainly of multifactorial origin. Part of the wide clinical spectrum of $H$ pylori infection might be explained by strains with different virulence. In our study most $H$ pylori strains capable of activating and agglutinating neutrophils were from patients with peptic ulcer disease. This might indicate that in some patients an $H$ pylori strain with increased virulence is of considerable importance. On the other hand, in peptic ulcer patients with a less virulent strain other factors might dominate. $H$ pylori strains with such virulence were also found in few patients with active chronic gastritis without verified peptic ulcer disease. It might be possible, however, that these patients also suffer from this disease - although an ulcer has never been found - or that they will later develop a peptic ulcer. Future studies will confirm if ulcerogenic strains can be differentiated from others with the help of simple indicators like those shown in the present work.

We thank the Research Committee of Örebro County Council and the Örebro Medical Centre Research Foundation for financial aid; Associate Professor Lennart Bodin, Occupational Medicine, for Associate Professor Lennart Bodin, Occupational Medicine, for
statistical advice; Associate Professor T U Kosunen, University of statistical advice; Associate Professor T U Kosunen, University of 11637, C 7050, F 6, and F 88; and Mrs Margaretha Jurstrand for excellent technical help.

1 Warren JR, Marshall B. Unidentified curved bacilli on gastric epithelium in active chronic gastritis. L ancet 1983; i: 1273-5.

2 Marshall BJ, Armstrong JA, McGechie DB, Glancy RJ Attempt to fulfil Koch's postulates for pyloric campylobacter. Med f A ust 1985; 142: 436-43.
3 Morris A, Nicholson G. Ingestion of Campylobacter pyloridis causes gastritis and raised fasting gastric pH. Am f Gastrocauses gastritis and raised
enterol 1987; 82: 192-9.

4 Rathbone BJ, Wyatt JI, Worsley BW, Shires SE, Trejdosiewicz LK, Heatley RV, et al. Systemic and local antibody responses to gastric Campylobacter pyloridis in nonulcer dyspepsia. Gut 1986; 27: 642-7.

5 Langenberg W, Rauws EAJ, Houthoff HJ, Oudbier JH, van Bohemen CG, Tytgat GNJ, et al. Follow-up study of individuals with untreated Campylobacter pylori-associated gastritis and of non-infected persons with non-ulcer dyspepsia. F Infect Dis 1988; 157: 1245-9.

6 Danielsson D, Blomberg B, Järnerot G, Kosunen TU. Heterogeneity of Campylobacter pylori as demonstrated by geneity of Campylobacter pylor as demonstrated by
co-agglutination testing with rabbit antibodies. Scand $\mathcal{F}$ Gastroenterol 1988; 23 (suppl 142): 58-63.

7 Blomberg B, Järnerot G, Kjellander J, Danielsson D, Kraaz W. Prevalence of Campylobacter pylori in an unselected Swedish population of patients referred for gastroscopy. Scand $\mathcal{F}$ Gastroenterol 1988; 23: 358-62.

8 Emödy L, Carlsson $\AA$, Ljungh $\AA$, Wadström T. Mannoseresistant haemagglutination by Campylobacter pylori. Scand F Infect Dis 1988; 20: 353-4

9 Tam MR, Buchanan TM, Sandström EG, Holmes KK, Knapp JS, Siadak AW, et al. Serological classification of Neisseria gonorrhoeae with monoclonal antibodies. Infect Immun 1982; 36: 1042-53.

10 Kosunen TU, Höök J, Rautelin HI, Myllylä G. Agedependent increase of Campylobacter pylori antibodies in blood donors. Scand $\mathcal{F}$ Gastroenterol 1989; 24 : 110-4.

11 Böyum A. Seperation of blood leukocytes, granulocytes and lymphocytes. Tissue Antigens 1974; 4:269-74.

12 Fredlund $\mathrm{H}$, Olcén $\mathrm{P}$, Danielsson D. A reference procedure to study chemiluminescence induced in polymorphonuclear leukocytes by Neisseria meningitidis. APMIS 1988; 96: 941-9.

13 Kronvall G, Myhre E. Differential staining of bacteria in clinical specimens using acridine orange buffered at low $\mathrm{pH}$. Acta Pathol Microbiol Scand Sect B 1977; 85: 249-54.

14 Fine DP, Marney Jr SR, Colley DG, Sergent JS, Des Pre RM. C3 shunt activation in human serum chelated with EGTA. F Immunol 1972; 109: 807-9.

15 Pratt JW, Gibbons JD. Concepts of nomparametric theory. New York: Springer-Verlag, 1981.

16 Babior BM. Oxygen-dependent microbial killing by phagocytes. NEnglfMed 1978; 298: 659-68.

cytes. NEnglf Med 1978; 298: 659-68.
17 Das SS, Karim QN, Easmon CSF. Opsonophagocytosis of Campylobacter pylori. F Med Microbiol 1988; 27: 125-30.

18 Bernatowska E, Jose P, Davies H, Stephenson M, Webster D. Interaction of Campylobacter species with antibody, complement and phagocytes. Gut 1989; 30: 906-11.

19 Tosi MF, Czinn SJ. Opsonic activity of specific human IgG against Helicobacter pylori. F Infect Dis 1990; 162: 156-62.

20 Pruul H, Lee PC, Goodwin CS, McDonald PJ. Interaction of Campylobacter pyloridis with human immune defence mechanisms. F Med Microbiol 1987; 23: 233-8.

21 Mooney C, Keenan J, Munster D, Wilson I, Allardyce R, Bagshaw P, et al. Neutrophil activation by Helicobacter pylori. Gut 1991; 32: 853-7.

22 Nielsen H, Andersen LP. Chemotactic activity of Helicobacter pylori sonicate for human polymorphonuclear leucocytes and pylon sonicate for human polymorp
monocytes. Gut 1992; 33: 738-42.

23 Leunk RD, Johnson PT, David BC, Kraft WG, Morgan DR. Cytotoxic activity in broth-culture filtrates of Campylobacter pylori. F Med Microbiol 1988; 26: 93-9.

24 Figura N, Guglielmetti P, Rossolini A, Barberi A, Cusi G, Musmanno RA, et al. Cytotoxin production by Campylobacter pylori strains isolated from patients with peptic ulcers and from patients with chronic gastritis only. $\mathcal{F}$ Clin Microbiol 1989; 27: 225-6. 